\title{
Reflexões diante de uma vitrine
}

\author{
Hans Magnus Enzensberger \\ Tradução de BEATRIZ SIDOU
}

\section{DEFINIÇŌES}

O que é um crime, nós sabemos sem o saber. A Enciclopédia Britânica nos dá as seguintes indicações sobre este verbete: "Crime... designação geral das infrações à legislação criminal. O crime foi definido como um desprezo ou recusa das normas de comportamento que, de outro modo, a coletividade considera como obrigatórias". Sir James Stephen o descreve como uma "ação ou omissão pela qual a pessoa a quem se inculpa pode ser punida pela lei"(1). A definição de Thomas Hobbes não é muito diferente - há trezentos anos ele escreveu: "Um crime $\varepsilon$ um pecado que comete aquele que, por atos ou palavras, faz o que a lei proíbe ou se abstém de fazer o que ela ordena"(2). A estrutura iautológica destes parágrafos está evidente e, como todas as tautologias, é reversível: o que é punido é um crime e o que é um crime é punido; tudo o que é passível de punição nierece ser punido e vice-versa. $O$ modelo sintático desse gênero de definições deve ser buiscado no dogma bíblico: “Eu sou O que é!" Elas colocam o legislador além de qualquer lógica, além de qualquer raciocínio. O direito codificado se apropria desta forma de linguagem. No Código alemão, $e$ dito de maneira diferente: "Um ato punido com a prisão ou com um encarceramento de mais de cinco anos ê um crime".

Não são poucas as vantagens práticas de uma definição que exclua quaisquer discussões. Ela dispensa de uma vez por todas o exercício da jurisdição de colocar a questão do crime em si, e repassa o trabalho teórico sob a forma de especialidade a espíritos sagazes. Nas escolas, nos entregamos a intermináveis considerações sobre a "noção material do crime", sem que surja nada de muito conclusivo. Como surpreender-se, quando a própria legislação criminal já não é mais um sistema concludente, e sim um ajuntamento muitŕssimo heterogêneo e até bastante estranho em que historicamente se empilham disposições destinadas a "proteger os bens legítimos" e os mais diversos interesses, as mais variadas concepções dos tabus e da moral e simples regras do jogo sem nenhum valor pragmático?

De resto, os jurisconsultos encontram-se em um caso muito comum. Quanto mais um fenômeno é geral, mais ele é fundamental, mais sua concepção é vaga. Todo mundo (e ninguém) sabe explicar o que é uma nação (embora cada um o faça de maneira diferente). Todo mundo conhece o dinheiro, muitos sabem lidar com ele, mas os economistas não conseguem entrar em acordo a respeito da questão de saber o que é ele. $O$ que é a saúde? A medicina faz suposiçōes. O que é a morte? Os biólogos respondem através de afirmações dogmáticas.

Em casos do gênero, talvez seja melhor descer até a rua e interrogar os dez primeiros passantes que se encontrar. A resposta mais freqüente não é uma definição, mas um exemplo - e, muito curiosamente, sempre o mesmo: "Um crime $\epsilon$, por exemplo, um assassinato". A freqüência desta resposta não tem relação alguma com as estatísticas cri-

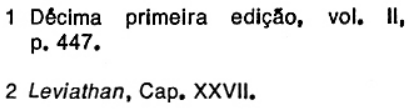

HANS MAGNUS ENZENSBERGER é poeta, tradutor e ensaista alemão. Tendo publicado nos anos 50 suas primeiras obras, tornou-se famoso como um dos principais nomes da poesia alemã do pós-guerra e dedicou-se tanto à critica literária quanto ao ensalsmo polftico. A Editora Brasiliense publicou uma antologia de seus poemas, Eu falo dos que não falam; a Companhia das Letras, as reportagens contidas em $A$ outra Europa; e a Paz e Terra, os ensaios de Com raiva $e$ paciência. 
minais, em que delitos completamente diferentes desempenham o papel principal. Embora relativamente raro, o homicídio tem uma posição-chave na consciência popular. É pelo seu exemplo que se começa a apreender a idéia do que seja um crime.

Os romances e filmes policiais, reflexos desta consciência popular, confirmam que o assassinato ocupa o lugar central - ou melhor, ele é, por assim dizer, confundido com a noção de crime.

O fato de ser o homicídio o crime original, o crime capital em si, é algo que tem a ver com a lei de Talião e o castigo que ela preconiza: esta punição, a mais antiga, a mais radical e, até quase o final da Idade Média, a punição fundamental - ou seja, a pena de morte pressupõe aquilo que deseja fazer pagar: o homicídio.

\section{ANTROPOLOGIA DO CRIME}

Não possurmos nenhum dado sério sobre a origem do crime. Encontramos os "violadores da justiça" nas sociedades primitivas atualmente acessfveis ao observador, mesmo quando estão ausentes as regras codificadas. Nos documentos relativos às épocas mais remotas da humanidade, o assassinato desempenha um papel considerável. Como a situação original não pode de maneira alguma ser empiricamente concebível, qualquer pesquisa a respeito de sua história permanece hipotética. Restam à disposição do pesquisador as seguintes fontes: a ciência do comportamento biologico (que, para falar a verdade, não permite mais do que certas deduções sobre a atitude humana), a etnologia, a ciência dos mitos e também a psicanálise.

É a Sigmund Freud que devemos a hipótese clássica do "primeiro crime". Ela decorre da "horda primitiva" de Darwin: "Um pai violento, ciumento, que conserva para si todas as fêmeas e caça os filhos adolescentes, nada mais". O crime em si é descrito da seguinte maneira: "Um dia, os irmãos caçados se reuniram, mataram e comeram o pai, o que deu fim à horda paterna. Uma vez reunidos, eles se tornaram empreendedores e conseguiram realizar o que cada um deles, tomado individualmente, teria sido incapaz de fazer. $\mathrm{O}$ avô violento era certamente o modelo invejado e temido por todos os membros dessa associação fraternal. Ora, através do ato de absorção, realizavam sua identificação com ele, cada um apropriando-se de uma parte da sua força. A refeição totêmica, que é talvez a primeira festa da humanidade, seria a reprodução e uma espécie de festa comemorativa deste ato memorável e criminoso que constitui o ponto de partida de tantas coisas, organizações sociais, restrições morais, religião"(3). Esta hipótese pressupõe a evidente objeção de que não pode haver crime onde não há lei. Este gênero de escrúpulo é jurídico e não filosófico; é um círculo vicioso: a questão especiosa a que leva se parece com aquela da prioridade do ovo ou da galinha. É somente pela culpa, enquanto limite, que o direito pode ser definido, pode ser reconhecido como tal. As "restrições morais" não devem ser consideradas senão como resposta a uma provocação. Neste sentido, o crime original é sem a menor dúvida um ato criador. (Walter Benjamin em Zur Kritik der Gewalt tratou da sua força para colocar em vigor a lei.)

A hipótese que Freud expôs em seu estudo sobre o retorno infantil do totemismo é, ao mesmo tempo, célebre e desconhecida - e por razões muito simples. Freud iludiu-se um pouco sobre a resistência com que lutaria sua tentativa de fazer "remontar o início dos nossos bens culturais dos quais por direito temos tanto orgulho a um crime abominável que ofende todos os nossos sentimentos". Excetuando-se os especializados na questão, o seu "mito científico" não chegou a ser discutido, mas foi simplesmente igno-

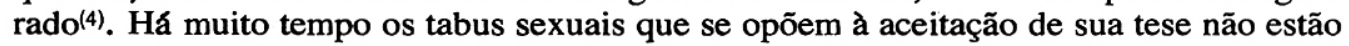
em primeiro lugar, e sim as suas conseqüências sociais e políticas. Quanto mais essas conseqüências aparecem historicamente evidentes, mais nos obstinamos em rejeitá-las.

\section{Política e ASSASSINATo}

Portanto, $o$ ato político original, se acreditamos em Freud, confunde-se com o crime original. Entre o assassinato e a política existe um relacionamento antigo, estreito e obscuro. Até aqui ele foi conservado na estrutura fundamental de todos os governos e o governo pertence a quem quer que possa mandar matar aqueles sobre quem reina. $\mathrm{O}$ soberano é o "sobrevivente". A definição é de Elias Canetti, a quem devemos uma notável fenomenologia do governo(5). 
A linguagem da política hoje ainda reflete $o$ ato criminoso que a fundou. Nas batalhas eleitorais, por mais inofensivas $e$ civilizadas que sejam, um dos candidatos "bate" o outro (o que na realidade significa que o abate, mata-o); um governo é derrubado (ou seja: cai no chão, é esmagado); os ministérios "caem". O que ê simbolicamente conservado nessas expressōes se desenvolve e se realiza nas situações sociais extremas. Nenhuma revolução pode se abster de matar o antigo soberano. Ela é obrigada a romper $o$ tabu que próbe os dominados de o atacarem - porque somente "quem conseguiu transgredir esta proibição adquire o caráter do que é proibido"(6). $\mathrm{O}$ mana do soberano morto se transfere para o seu assassino. Até hoje todas as revoluções foram contaminadas pelo antigo estado prérevolucionário e herdaram a estrutura básica do governo contra o qual se insurgiram.

\section{CONTRAdiçÃo}

As organizações sociais mais "progressistas", mais civilizadas previam também o assassinato de seres humanos por outros seres humanos, mas em casos extremos, como, por exemplo, na revolução ou na guerra. Por outro lado, a estrutura fundamental do governo não se mostra à luz do dia permanece escondida. Antes ou depois, a ordem é uma "condenação por morte dependurada" (Canetti). Esta condenação, entretanto, não se expressa como uma ameaça perpetuamente recolocada, ela existe apenas virtualmente ${ }^{(7)}$. Esta restrição aparece institucionalmente estabelecida na história sob o nome de "direito".

$O$ fato de estar o direito, como qualquer ordem social, fundamentado no crime original, baseado na culpa, é uma contradição que todos os filósofos jurídicos se esforçaram por resolver - em vão! Até aqui, toda regra de direito é ao mesmo tempo uma proteção contra a autoridade e o seu instrumento. Talvez se pudesse conceber toda a história do direito como a de sua separação da esfera política. Este processo colossal só pode ser esclarecido por especialistas competentes; contudo, parece que não se conseguiu encontrar a solução das contradições íntimas de sua razão de ser que ele arrasta consigo. A separação entre os poderes executivo, jurídico e legislativo; a independência e imobilidade dos juízes; a dissociação que há no ministério público entre juízes e advogados e a sua instauração como "partido"; a multiplicidade das garantias asseguradas ao direito judiciário - tudo isto representa mediações de valor inestimável. No entanto, o soberano permanece ao mesmo tempo a mais alta instância da justiça e o juiz, enquanto "personagem imparcial", é sempre, ao mesmo tempo também, um servidor do Estado.

É no problema da punição que esta dupla natureza do direito aparece com a maior clareza. Se cada prescrição é uma "condenação à morte suspensa", a punição que dela resulta, por mais branda que seja, representa a sua execução. A morte é o castigo mais antigo, o mais considerável: é o castigo em si. Com a sua supressão, o dever e o direito de punir que tem o Estado passam de obscuras representações religiosas e mágicas para o campo da superioridade racional. Com a pena de morte, o castigo se presta muito bem à discussão - o que explica porque os espíritos e as constituições se dividiram a esse respeito. Isso basta para motivar a paixão com a qual se luta a favor ou contra ela. Não se trata da possibilidade de erros judiciários, nem da simples piedade pelos justiçados, menos ainda da intenção de proteger a sociedade dos criminosos que alimentam esta
6 -Tabu e ambivalencia dos sentimentos", in Freud, Totem e tabu, Viena, 1913.

7 Canetti, ob. cit., p. 542. 


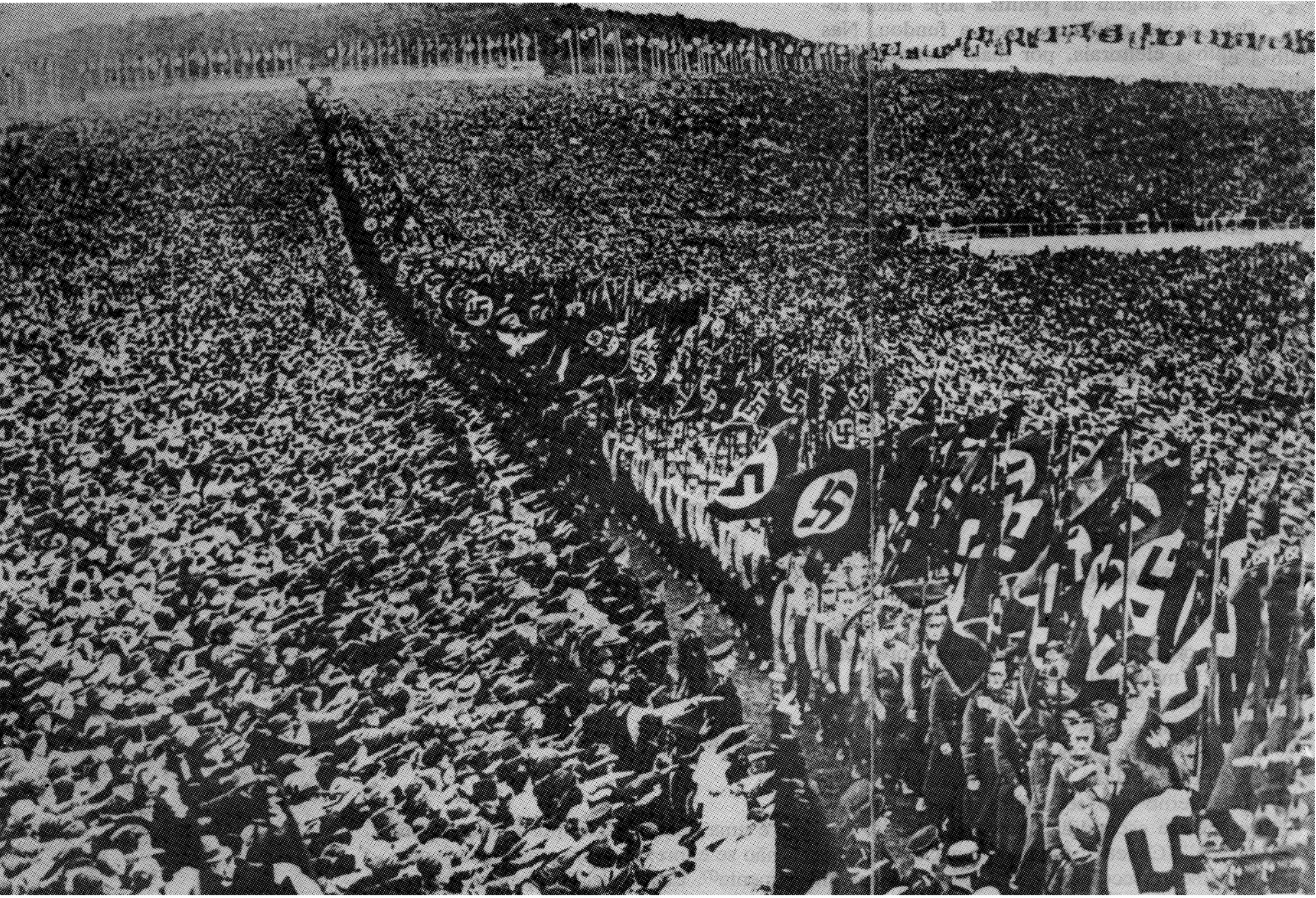

Manifestação nazista na Alemanha pré-2ª Guerra disputa. Pouco importa o que pretendem os partidários da pena de morte: uma certa histeria trai seu desejo de uma autoridade absoluta com a qual se possam identificar. $\mathrm{O}$ que é vetado a um indivíduo, a faculdade de "impedir outros seres humanos de incomodar" e, portanto, de matá-los - lhe é permitido enquanto membro da coletividade. Daí provém a curiosa mística que o acompanha: a de um rito. $\mathrm{O}$ fato de outrora a pena de morte ter sido executada em público tem uma lógica - matar em nome de todos só pode acontecer publicamente, porque todos têm parte nisso: o algoz é apenas o nosso executor.

A abolição da pena de morte, plenamente refletida, transformaria a natureza do Estado. É uma antecipação de contratos sociais dos quais ainda estamos muito distantes. Retira à autoridade do Estado o poder de decidir a vida ou a morte do indivíduo. E este poder ê a própria essência da soberania.

\section{SOBERANIA}

O historiador alemão Heinrich von Treitschke escreveu: "A soberania no sentido jurídico da palavra, a completa independência do Estado de quaisquer outros poderes existentes de tal maneira faz parte de sua essência, que se pode dizer que seja o critério da natureza do Estado"(8). O poder desta mistificação continua imutável, embora não haja dúvidas de que jamais tenha existido uma soberania tomada neste sentido. Desta idéia decorre que o Estado esteja além de qualquer direito, ou seja, acima dele. Para aquele que se atém a esta concepção, não pode haver o direito das pessoas. A soberania e o direito das pessoas se excluem mutuamente.

A respeito disso, uma obra de referência de 1959 constata: “A existência atual de um
8 Das Fischer Lexikon, vol. XII: Recht, Frankfurt-am-Mein, 1959, p. $137 \Theta$ segs.

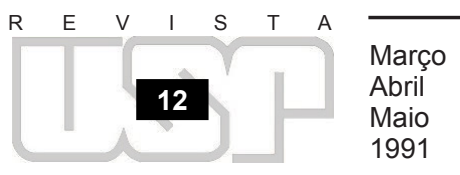


direito das pessoas parece muito duvidosa (...) O que até agora se chamou de direito das pessoas - ou direito internacional - essencialmente limitou-se a desenvolver regras diplomáticas destinadas à troca de explicações e a estabelecer as regras do jogo em caso de guerra (...) Ainda não existem normas sociais obrigatórias entre Estados"(9).

A expressão mais absoluta da soberania do Estado como Treitschke a concebe é, internamente e em suas relações com o indivíduo, a pena de morte; externamente e em suas relações com outros Estados, é a guerra. Se o Estado, em seu papel de soberano colocado acima do direito, pode matar os indivíduos, ele tamberm pode, da mesma forma, em seu nome e em nome deles, mandar matar muitos, senão todos, e fazer do cumprimento deste ato de soberania um dever para todos os cidadãos.

"Cada cidadão de uma nação", escreveu Freud a propósito da Primeira Guerra Mundial, "pode, com horror, constatar no decorrer desta guerra um fato que vagamente já havia intuído em tempos de paz - a saber: se o Estado profbe ao indivíduo o recurso à injustiça, não é por desejar suprimir a injustiça, mas porque deseja monopolizar este recurso da mesma forma que monopoliza o sal e o tabaco. $O$ Estado em guerra se permite todas as injustiças, todas as violências, a menor das quais desonraria o indivíduo (...) Não me venham dizer que o Estado não pode renunciar ao recurso à injustiça porque, se a ela renunciasse, colocar-se-ia em situação de inferioridade. Conformar-se com as norinas morais, renunciar à atividade brutal e violenta é tão pouco vantajoso para $o$ indivíduo quanto o é para o Estado, e este raramente se mostra disposto a ressarcir o cidadão dos sacrifícios que exige dele"(10).

Mais que pela violência, da qual já deram prova os Estados nacionais na Primeira Guerra Mundial, hoje nos surpreendemos com o espanto burguês diante de sua obra e sua catástrofe. A reflexão mais simples demonstra que o assassinato privado jamais pôde comparar-se ao assassinato púl lico no curso da história. Todos os crimes violentos, de Caim a Landru, nada pesam na balança, quando comparados aos males causados pelas guerras européias de sucessão no século XVII ou aos atos de dominação colonial em uma única década.

Reflexões como essas, é claro, passam por diletantismo. Os homens de Estado e os juristas com autoridade jamais se detiveram nelas por muito tempo. Compreende-se a reserva. A relação entre a política e o crime jamais foi completamente esquecida. Conservou-se também como uma espécie de intuição no século XIX. Rechaçada para os limites extremos da consciência e também para os limites extremos da sociedade, o problema tornou-se domínio dos outsiders. Quem quis ocupar-se dele, como Freud, está em companhia duvidosa, no meio dos grandes heréticos e dos pequenos briguentos, dos frustrados e dos explorados, dos santos exóticos e dos sectários de todas as cores. Quanto mais uma sociedade é segura de seus postulados, menos ela admite que os outsiders a coloquem em dúvida. O século XIX burguês conseguiu sufocar todos os ataques à mão armada contra sua forma de governo, mas autorizou as discussões mais radicais de seus fundamentos como um passatempo bom para os utopistas. Não é por nada que ainda hoje se considera o cúmulo do ridículo a idéia de reformar o mundo, enquanto os esforços contrários contam sempre com alguma estima. É pelo ridículo que se punirá quem pretenda levar a sério os ensinamentos da Segunda Guerra Mundial. Apenas o ridículo não mata. Prova disso são os cacetetes de borracha e os processos, chamados em socorro.

\section{6. ÉPOCA}

Quem deseja saber em que época vive hoje tem apenas de abrir um jornal qualquer. Saberá que está no século da fibra sintética, do turismo, das provas esportivas ou do teatro do absurdo. Em sintonia com essa atmosfera, a consciência industriosa soube rir da lei que deseja que a nossa época seja batizada com os nomes de Auschwitz e Hiroshima. Vinte anos depois deste batismo, esta lei já se tornou um lugar-comum tirado de uma crônica da civilização. Leis autênticas hoje caem em desuso mesmo antes de entrarem em vigor e são tratadas como bens de consumo efêmero que se joga fora à vontade e que se substitui pelos modelos mais recentes. Tudo o que se expressa parece submetido a este processo de envelhecimento artificial; acredita-se desfazer de uma lei jogandoa fora. Mas é mais fácil desfazer-se de uma mercadoria do que da verdade.

$\mathrm{O}$ que aconteceu durante quarenta anos não envelhece; em lugar de se afundar na noite do tempo, isto nos cai em cima e nos obriga a uma revisão de todas as nossas

9 Politik, Leipzig, 1897.

10 "Zeitgemässes über Krieg und Tod" (1915), in Das Unbewusste. Schriften zur Psychoanalise (Consideraçס̄es atuais sobre a guerra e a morte, extrafdo de S. Freud, $C$ inconsciente. Ensaios de psicanálise). Frankfurt-am-Mein, 1960, p. 191 e segs.

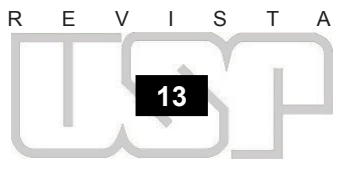


idéias e de todos os relacionamentos humanos. Não podemos impor a nossa concepção antiga da justiça e da injustiça, do crime, do Estado, se não ao preço de um eterno risco de morte para nós e para nossos filhos.

Não é descoberta saber que os Estados nacionais modernos e seus partidários sejam moralmente capazes de tudo: desde o século passado os porta-vozes do imperialismo proclamam isso com orgulho. Desde então, também sabemos que eles da mesma forma são capazes de tudo, falando-se em termos técnicos. A antiga relação entre o crime e a política, as contradições interiores do direito, a megalomania da soberania obrigam-nos a que se tornem cada vez mais violentos, terminando por "rebentar", no sentido literal e explosivo da palavra.

Nada pode permanecer como era e como é ainda. Mas todos sabem, sob pena de suić́dio, que a revisão a que estamos obrigados apenas começou e já se prepara para tomar de emprestimo o jargão altamente especializado da "dominação" a suprimir. A realidade do nome de Auschwitz deve ser exorcizada como se pertencesse ao passado - ou melhor, ao passado nacional: não a um presente e a um futuro comuns. Para isso nos servimos de um ritual complicado de auto-acusações locais que não comportam nenhuma seqüência. Este ritual deseja acabar com um acontecimento que revelou claramente as origens da política como ela tem sido praticada até hoje (o que, no final das contas, seria como dizer esquecê-la) sem ter de trazer as conseqüências a que estariam restritos os participantes (não há não-participante). Está claro que uma "dominação" desse tipo só pode ser estéril, incapaz de resolver suas conseqüências mais superficiais e mais evidentes. Com maior razão, que venha a suprimir os postulados que tornaram este acontecimento possível. A idéia fixa da soberania, por assim dizer, não foi abalada por isso. Antes ou depois, o "próprio caráter do Estado é o de não poder tolerar nenhuma autoridade acima de si" (Treitschke). Antes ou depois, a soberania, vista por este ângulo, passa pelo "criterio da própria natureza do Estado" - a não ser que, aos olhos dos "lrderes" políticos e militares alemães, quinze anos depois da derrota alemã e da destruição de Hiroshima, o critério deste critério tornou-se a posse da arma nuclear.

Acontece que esta arma é o presente e o futuro de Auschwitz. Com que direito alguém, dispondo de toda espécie de recursos cientfficos e industriais que lhe permitem projetar e preparar cuidadosamente o genocídio de amanhã, pretende condenar, ou antes "dominar", o genocídio de ontem? A arma nuclear faz cair das mãos de seus senhores (na verdade, seus servidores) todas as razões tiradas do arsenal das ideologias, em honra das quais se armaram. Ela não pode servir para a defesa dos direitos e das liberdades; ao contrário, por sua existência mesmo, a arma nuclear tem suspensos todos os direitos humanos: o direito de passear, o direito de fundar partidos, o direito de trabalhar ou o de comer - estes, como todos os outros, existem apenas sob a sua proteção, ou melhor, sob a sua ameaça, à sua mercê, e estão sempre sob o risco de tornarem-se um simples sinal de benevolência que pode ser revogado a qualquer momento. É assim também que a arma nuclear suprime todas as liberdades políticas e só autoriza a democracia com restrições que a colocam em risco. Como a crise cubana demonstrou aos piores cegos, ela retira de uma vez por todas dos parlamentos as verdadeiras decisões e as coloca nas mãos de um número muito pequeno de indivíduos - cada um dos quais é o mais poderoso, o mais solitário, pode e deve decidir de modo mais irrevogável do que qualquer déspota da história. Qualquer chamamento ao sistema coercitivo da estratégia é impotente. Os nazistas tamberm tinham o seu sistema coercitivo. (Hannah Arendt, entre outros, o descreveu com toda a precisão que se possa imaginar.) Não menos paranóide do que a idéia obsessiva da "conjuração judaica mundial", o princípio da corrida armamentista | lai atrás de um objetivo por demais conhecido para que ainda seja necessário falar a respeito. A arma nuclear não é uma arma na luta de classes; não é nem uma arma capitalista, nem uma arma comunista; não é de modo algum uma arma, mais do que o seja a câmara de gás.

Sendo assim - ou, mais precisamente, dadas as condições que reinam há mais de vinte anos em nosso universo - quem quer que tenha leis a impor ou direitos a expressar, encontra-se numa situação curiosa. Esta situação é fácil de elucidar. Não faltam exemplos.

\section{PRIMEIRO EXEMPLO: PROTEÇÃo DOS ANIMAIS}

Decreto referente ao abate e conservação de peixes vivos e outros animais de sangue

R

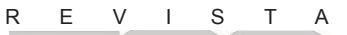


frio, com a data de 14 de janeiro de 1936:

“§ 2. Os camarões de água doce, lagostas e outros crustáceos cuja carne se destina ao consumo humano devem ser mortos de maneira que seja possível lançá-los em separado na água fervente. É proibido mergulhá-los em água fria ou morna para depois cozinhá-los."

Despacho de Berlim, no 234404, datado de 9 de novembro, dirigido a todos os postos e comissariados de polícia do Estado:

“1. Muito em breve iremos empreender em todo o paŕs ações contra os judeus e principalmente contra as suas sinagogas. Em nenhum caso poderá haver oposição. (...)

“3. Preparar-se para a prisão de 20.000 a 30.000 judeus em todo o paŕs. Escolher em primeiro lugar os judeus ricos. Instruções mais detalhadas serão publicadas durante a noite. (...)

“Gestapo II - assinado: Müller”(11).

Decreto sobre a proteção das plantas selvagens e os animais que não se caça, com a data de 18 de março de 1936:

“§ 16. Os proprietários de terras, as pessoas que têm direito de usufruto ou seus mandatários, estão autorizados a capturar sem fazer mal e a tomar conta de gatos estranhos ou sem vigilância que sejam encontrados durante um lapso de tempo que vai do dia 15 de março a 15 de agosto e pelo tempo em que perdure a neve sobre os jardins, pomares, cemitérios, parques e estabelecimentos análogos. Os gatos recolhidos deverão ser bem tratados (....)"

Despacho de Varsóvia, no 663/43, de 24 de maio de 1943, dirigido aos oficiais superiores das SS e da polícia do leste:

“1. Do total de 56.065 judeus apreendidos, 7.000 sucumbiram depois de uma grande ação realizada no velho bairro judeu. Durante o transporte à $T$. II, 6.929 judeus morreram, de maneira que, no conjunto, 13.929 judeus foram eliminados. Além disso, estima-se que a este número de 56.065, 5.000 ou 6.000 judeus perderam a vida depois de explosões ou incêndios. (...) $\mathrm{O}$ Führer das SS e da polícia do distrito de Varsóvia. Assinado: Stroop"(12).

Extraído das conversas de Hitler com seu massagista:

"Como é que o senhor pode sentir qualquer prazer em atirar sobre esses pobres animais que estão pastando com tanta inocência, que estão ali na floresta sem nenhuma defesa e que ignoram o que os espera, Herr Kersten? Na verdade, é puro assassinato... A natureza é muito bela e os animais têm todo o direito de viver. É este modo de ver que eu tanto admiro em nossos ancestrais... Esse respeito pelos animais existe em todos os povos indo-germânicos. Outro dia eu soube, com o maior interesse, que ainda hoje os monges budistas não saem para passear na floresta sem um sininho de aviso aos pequenos animais em que poderiam pisar sem ver, para que saiam de seu caminho para não lhes fazerem mal. E pensar que entre nós ninguem hesita em pisar nas lesmas e que esmagamos os vermes!'(13)

Discurso de Heinrich Himmler aos SS-Gruppenführern, em Posen, no dia 4 de outubro de 1943:

"A maioria dos senhores sabem o que representam cem cadáveres empilhados, quando trezentos ou mil outros estão sobre o chão. Ter resistido a tudo isso e - com raríssimas exceções, devido a uma fraqueza muito humana sem que por isso nos tenhamos tornado menos honestos, fez com que tenhamos endurecido. Esta é uma página gloriosa da nossa história que ainda não foi e que jamais será escrita!'(14)
11 Gerard Schoenberner, Der gelbe Stern. Die Judenverfolgung in Europa 1933 bis 1945, Hamburgo, 1960, p. 12.

12 Es gibt keinen jüdischen Wohnbezirk in Warschau Mehr! (ediçăo em fac-simile do relatório Stroop), Newied, 1960.

13 Feliz Kersten, Totenkopf und Treue, p. 144 e segs., citado a partir de Joachim C. Fest. Das Gesicht des Dritten Reiches, Munique, 1963, p. 169 e segs.

14 Tribunal militar internacional. Der Prozess gegen die Hauptkriegverbrecher. Nurembergue, 1947, vol. XXIX, p. 145. 
Decreto referente à proteção das plantas selvagens e dos animais que não se caça:

“§ 23. A fim de proteger os animais selvagens que não são caçados, ๔ proibido: capturar ou matá-los em massa sem um motivo razoável e justificado."

\section{SEGUNDO EXEMPLO - O JOGO DOS PLANEJAMENTOS}

Em abril de 1961 iniciou-se diante do tribunal supremo de Jerusalém o processo do antigo Oberstumbannführer A. Eichmann. A acusação não chegou a sustentar que o acusado houvesse feito funcionar com suas próprias mãos os fornos de gás. Eichmann coordenou minuciosa e conscientemente o assassinato de seis milhões de seres humanos.

Nesse mesmo ano de 1961 foi publicada em Princeton, Nova Jersey, uma obra que saiu da pena do matemático, físico e teórico militar Herman Kahn: On Thermonuclear War. Na página ao lado há o seguinte quadro:

(...)

"Exames objetivos mostram que a soma das tragédias humanas (sic) aumentaria enormemente no mundo do pós-guerra, mas que este aumento nem por isso exclui uma existência normal e feliz para a maior parte dos sobreviventes e seus descendentes.

(...)

Mas estes sobreviventes estariam em condiçōes de levar o tipo de vida a que estão acostumados como americanos, ou seja, uma vida com automóveis, com casas de campo, com geladeiras, etc.? Ninguém pode afirmar com certeza, mas acredito que se, por assim dizer, não fizéssemos nenhum preparativo tendo em vista a nossa reconstrução - excetuando-se a aquisição de contadores Geiger, a distribuição de manuais e determinados exercícios preventivos - o pais se recobraria relativamente depressa" ${ }^{(15)}$.

Os mortos em embrião não teriam senão

“uma importância relativa (...) É provável que na primeira geração se encontre cerca de cinco milhões de casos e uma centena de milhão nas gerações seguintes. Considero que este último número não pese muito na balança, independentemente da minoria dos casos em que se tratará de abortos completos ou de natimortos. Seja como for, a humanidade é tão fecunda, que uma pequena redução em sua fertilidade não tem razão para ser levada particularmente a sério, nem mesmo pelo indivíduo por ela atingido.

Que preço se deverá pagar para 'punir os russos pela sua agressão?' Levantei este problema junto a muitos norte-americanos e, de maneira geral, depois de apenas um quarto de hora de discussão a estimativa que tinham de um preço aceitável estava entre dez e sessenta milhões. Termina-se por admitir um número mais próximo à maior cifra... É muito curioso observar a maneira como se chega a este limite extremo. Na realidade, cita-se um terço da população de um país, ou seja, pouco menos da metade"(16).

A. Eichmann foi condenado à morte e enforcado em dezembro de 1961.

H. Kahn é membro consultivo do conselho científico da aviação militar americana, faz parte do comitê técnico da comissão da energia atômica, é especialista do departamento da defesa civil e proprietário do Hudson Institute de White Plains (Nova York), que fornece as perícias necessárias ao planejamento militar norte-americano. Kahn é casado, pai de dois filhos e goza de uma reputação de requintado gourmet.

Perguntas acessórias: pode-se comparar Kahn e Eichmann? Existem "exames objetivos" da "soma das tragédias humanas"? Que força moral demonstrativa atribuir a uma discussão que chama sessenta milhões de mortos de "preço aceitável"? O genocídio pode ser objeto de consideração e cálculo neutros, sem previsões? Onde estão as diferenças entre consideração e planejamento, cálculo e preparativo? Essas diferenças

$\mathrm{R}$

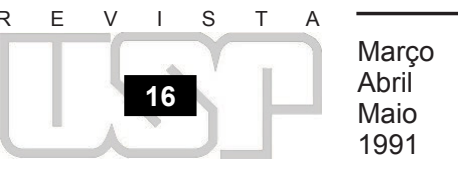




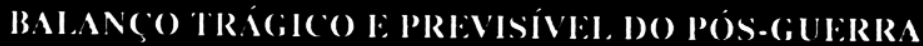

\begin{tabular}{|c|c|}
\hline Mortos & $\begin{array}{c}\text { Perfodo de reconstrução } \\
\text { da economia }\end{array}$ \\
\hline 2.000 .000 & 1 ano \\
5.000 .000 & 2 anos \\
10.000 .000 & 5 anos \\
20.000 .000 & 10 anos \\
40.000 .000 & 20 anos \\
80.000 .000 & 50 anos \\
160.000 .000 & 100 anos \\
\hline
\end{tabular}

"especialistas" a prevenção e o planejamento? A quem estes especialistas oferecem seus serviços? Suas intenções são levadas em conta? Seus projetos desempenham um papel? Quem os encomendou? Quem transmite as suas sentenças?

\section{TERCEIRO EXEMPLO - EMOÇĀO COMPREENSÍVEL}

Quantas pessoas estão prontas para obedecer incondicional e voluntariamente, mesmo sabendo que a execução de uma ordem causa em outro graves sofrimentos corporais?

Dispositivo da experiência: duas peças em que estão um painel de comandos elétricos e uma cadeira elétrica. Explica-se à "cobaia" humana que a experiência se destina a determinar até que ponto a memória de um adulto pode ser melhorada através de castigos corporais. Encarrega-se $A$ do papel de examinador ou professor. $O$ papel do examinando ou aluno $\hat{e}$ assumido pela "cobaia" humana, $B$. O promotor da experiência submete $B$ a um exercício de memória e, sob os olhos de $A$, o amarra à cadeira elétrica. $A$ vai para a peça vizinha, diante do painel de comandos. A cada erro de $B, A$ abaixa uma chave. Os choques são dosados segundo uma escala colocada no instrumento de tortura. O castigo começa com um choque de 15 volts e aumenta a cada erro. No vigésimo choque, de 300 volts, $B$ bate contra a parede divisória. Com 375 volts, aparece no painel um sinal de alarme: "Perigo: choques graves". As últimas chaves, que produzem 435 e 450 volts, estão indicadas apenas pela sigla XXX.

O dispositivo da experiência é fictício. Entre o painel de comando e a cadeira elétrica não há nenhuma ligação - os eletrodos não têm corrente e $B$ simula as suas reações. $\mathrm{O}$ examinador $A$ não sabe disso. Portanto, ele está na posição de um verdadeiro torturador.

Uma série de experiências desse gênero foi realizada na Universidade de Yale, em 1963, sob a direção de um psicólogo, o dr. Stanley Milgram. Todas as "cobaias" eram voluntárias e todas, bons cidadãos. Essas experiências deram um resultado: $65 \%$ das pessoas observadas executaram as ordens do diretor da experiência e, segundo as suas instruções, utilizaram todas as chaves colocadas à sua disposição(17).

No inf́cio de 1964, em Kempten, em Allgäu, o antigo ajudante-em-chefe, L. Scherer, foi levado a um tribunal. Era acusado de, na Segunda Guerra Mundial de ter ateado fogo e jogado granadas contra uma cabana de madeira na qual já havia encerrado quinze pessoas entre as quais homens, mulheres e crianças, recolhidas na região de Briansk durante uma busca pela floresta. $O$ professor Maurach, da Universidade de Munique, apresentou à Corte um relatório, sustentando a opinião de que, no momento da sentença, deveria ser levada em conta a "excitação e o afogueamento dos soldados". O assassinato de quinze homens, mulheres e crianças não lhe parecia "ilegal". O tribunal declarou-se incompetente. $O$ acusado, dizia a motivação da sentença, agira acreditando obedecer ao sentido das ordens recebidas.

Antes ou depois, segundo as regras do código penal alemão, serão punidos:

- quem circular pela cidade em um trenó sem leme fixo ou sem guizos ou campainhas $(\$ 366$, al. 4);

- quem por malevolência arrancar avisos, proclamações, decretos, ordens ou anúncios oficiais, emanando das autoridades ou dos serviços públicos (§ 304 , al. 1);

16 Ob. cit., p. 133 e passim.

17 Der Spiegel, $n^{\circ} 47 / 1963$, extrafdo do Journal of Abnormal and Social Psy chology, Boston, outubro de 1963. 
- quem, deliberada e ilegalmente, provocar a deterioração dos objetos destinados a ornamentar a via pública $(\S 304$, al. 1$)$;

- quem, como recurso para impedir doenças venéreas, fizer uma publicidade ofensiva aos bons costumes e à decência $(\$ 304$, al. 1$)$;

- quem alterar os símbolos da soberania da República Federal da Alemanha oficialmente estabelecidos pela autoridade ( $\S 96$, al. 2 );

- quem descuidar da desinfetação imposta por ordem legal ou policial (§ 368, al. 2).

\section{Personagem fictício}

O criminoso, no sentido tradicional do termo, como e visto sempre diante dos tribunais, pertence ao fundo mitológico de nossa época. Há muito tempo ele assumiu os traços de um personagem fictŕcio. Em nossa imaginação, ele tem un lugar que não é mais possível explicar através de seu significado real e com as suas ações, que não se explica mais pela realidade de sua existência. $O$ extraordinário e misterioso que resta é a paixão com que nos ocupamos dele e o enorme aparato que desenvolvemos para combatê-lo. É para ele uma publicidade louca. Pelas manchetes enormes, pode-se concluir que um simples assassinato monopoliza e excita muito mais os nossos espíritos do que uma guerra que se desenrola à distância - mais ainda, uma guerra que sequer foi declarada e que se limita aos preparativos. Em primeiro lugar, somos tentados a procurar a razão para este cuidado na força de inércia de nossa máquina judiciária. A justiça certamente se agarra com maior tenacidade do que qualquer outra instituição social - sem exceção das igrejas - às velhas concepções e às velhas formas, mesmo quando estas já não correspondem à realidade (tanto pior para a realidade). As razões mais recentes para uma pretensa reforma do código penal refletem o atraso cultural que contamina toda esta esfera; a linguagem de nossos códigos é tão rica em volteios arcaicos, que o leitor se vê obrigado a recorrer à filosofia. Residência obrigatória, atentado ao pudor, incendiário, tropas armadas, casa de correção e autoridade são fósseis da nossa língua em que se conservam situações históricas há muito superadas. Em certo sentido, podemos admirar a tenacidade com que o código penal se manteve intacto em um mundo heterogêneo.

Contudo, o papel do criminoso permanece institucionalmente inexplicável em nosso mundo. Quando se olha mais de perto para ele, percebemos que a ele se atribui um sistema de papéis que o torna indispensável e o eleva à categoria de uma figura mitológica.

\section{Paliativo}

Em primeiro lugar, o "criminoso comum" serve para tranqüilizar os espíritos. Sem dúvida o seu aparecimento desperta o medo na sociedade, mas esse medo é extraordinariamente inofensivo. Ao contrário das ameaças polf́ticas e militares, bem mais reais e às quais a sociedade está exposta, esta pode ser identificada. Seu instigador aparece nos cartazes da polícia pregados nos muros. Seu comportamento, em contradição com as necessidades atuais, é compreensível, previsível. Sua maneira de agir é passível de classificação no plano moral. Os códigos nos informam sobre o que devemos pensar. $\mathrm{Na}$ sorte reservada ao assassino (vê-se que "ainda há juízes") e em seu personagem se prende a ilusão desejável de que matar é proibido. Punindo o assassino, a sociedade se convence de que seu direito está intacto. É tranqüilizador.

\section{BODE EXPIATÓRIO}

Para o indivíduo, a condenação de um outro - de modo geral um criminoso é sempre considerado como este "outro" - equivale a uma prestação de contas. Quando se é culpado, se é castigado. Portanto, quando não se é castigado, se é inocente. A satisfação com que a coletividade observa a procura de um prisioneiro que fugiu está cheia de ensinamentos. De repente, caímos em metáforas tomadas de empréstimo da linguagem usada pelos caçadores. $O$ criminoso $€$ um animal selvagem que temos permissão para abater; através de um plebiscito, chegaríamos sempre a uma extensão do costume - de resto inqualificável - que tem a polícia de atirar ao menor pretexto. $O$ desejo da pena de morte é também muito popular; especialmente depois da descoberta de pretensos atentados aos costumes, que contêm uma enorme força publicitária e por ocasião dos quais vemos este desejo inchar em ondas de histeria. A tendência a transformar o criminoso em bode expiatório remonta à mais distante antigüidade; mas, nas atuais circunstâncias, 


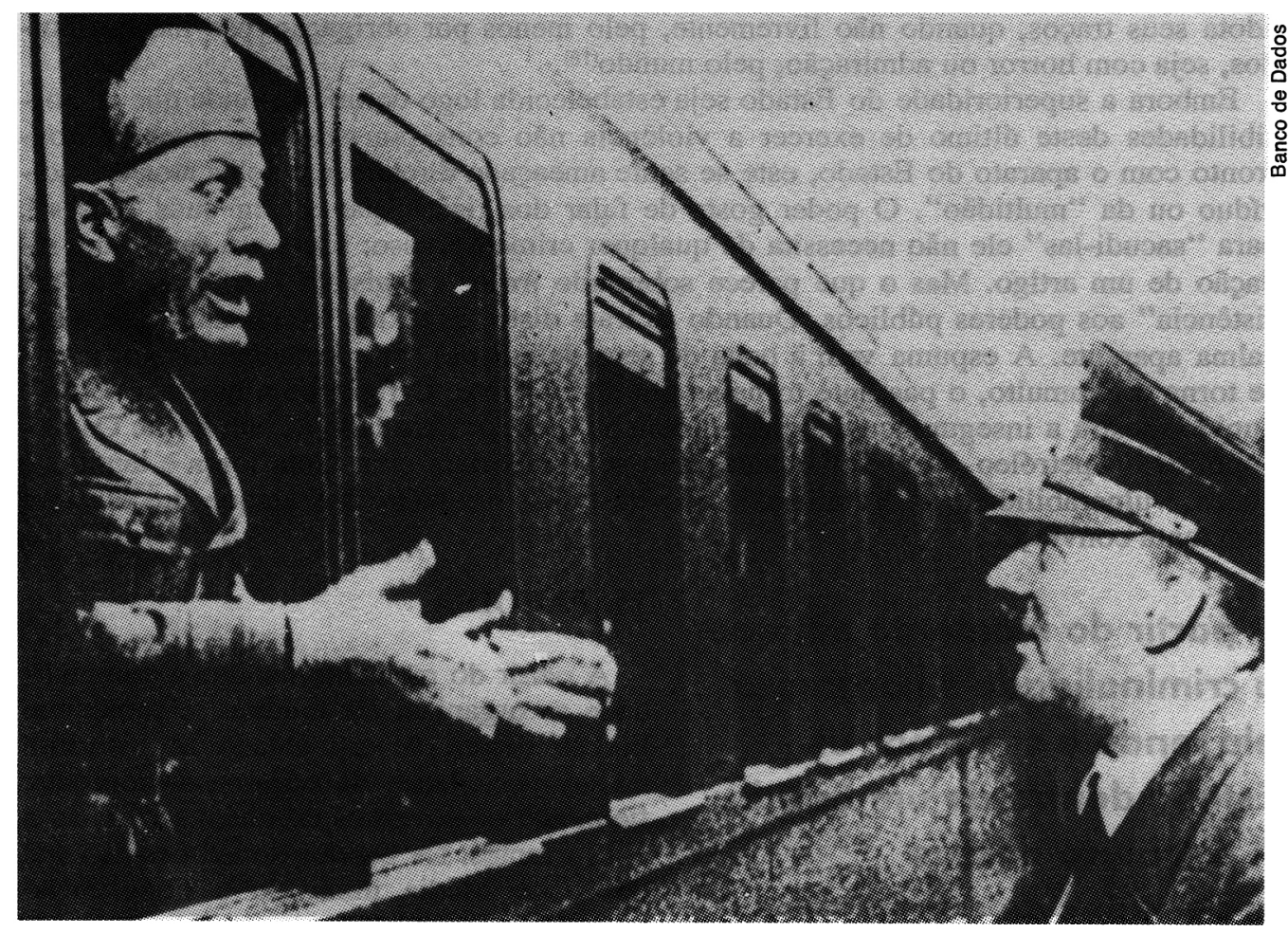

ela aparece com maior nitidez do que nunca. Quanto mais aumenta a culpabilidade coletiva, mais seus encadeamentos são difusos, mais anônimas e invisíveis as suas fontes, mais se torna urgente levar o peso a individuos isolados e facilmente reconhecíveis.

\section{O SUBSTITUTO}

Enquanto "substituto", suplente de todos, o criminoso, antes de receber seu castigo - o castigo -, age desde já em seu nome, ainda que sem a sua ordem. Ele faz apenas aquilo que todos desejariam fazer; melhor: ele o faz por sua própria iniciativa e, portanto, sem a concessão do Estado. A cólera que se manifesta porque ele se permite aquilo que todos se impedem de fazer, por estar proibido e ainda não haver sido ordenado, acalma-se quando se faz com que ele pague na mesma moeda, quando se repete contra o "substituto" a ação que ele cometeu. Para falar a verdade, esta repetição da ação não se dá diretamente, mas por intermédio do Estado, outra vez por alguém interposto, por meio de um "substituto". O que todos se recusam retorna-lhes em seguida sob uma forma simbólica e dupla: pela parte tomada à ação criminosa e pela parte tomada à sua punição. $O$ assassino e o algoz nos tomam o que desejamos ao mesmo tempo fazer e ser dispensados de executar; assim eles nos proporcionam não apenas um álibi moral, mas também o sentimento de uma superioridade moral. Talvez seja deste duplo sentimento que provém o surdo reconhecimento que o público às vezes manifesta para com determinados criminosos, em especial as "estrelas" da profissão. A eles se atribui a estima que de direito se aplica aos técnicos mais notáveis. O mal passa por uma esfera especial em que o criminoso evolui em virtude da sua habilidade. Por isso a sociedade, partidária da divisão do trabalho, tomou o cuidado de delegá-lo ao criminoso.

\section{CONCORRÊNCIA}

Não é só pelo indivíduo, mas também pela sociedade em geral que o criminoso intervém e se opõe a ela, e isto porque reivindica para si as suas prerrogativas; segundo as palavras do lenhador Paul Ackermann, do Alasca, ele toma por homem aquele que "pode poder tudo". Esta pretensão em seu espírito o coloca ao lado do Estado, mas às vezes também se opõe a ele. Nesse sentido, o criminoso é o concorrente do Estado - ele questiona seu monopólio do poder. Este papel também vem de longe. Os ladrões das estradas e os salteadores do passado o exploraram ao extremo e tudo o que é rebelião

extradas e os salteadores do passado o exploraram ao extremo e tudo o que e rebeliao 
adota seus traços, quando não livremente, pelo menos por obrigação: são-lhes atriburdos, seja com horror ou admiração, pelo mundo(18).

Embora a superioridade do Estado seja estabelecida logo de início, ainda que as possibilidades deste último de exercer a violência não consigam sustentar nenhum confronto com o aparato do Estado, este se sente ameaçado diretamente pelos atos do indivíduo ou da "multidão". O poder gosta de falar dos riscos que correm suas "bases"; para "sacudi-las" ele não necessita de qualquer crime devasso: basta um furto ou a redação de um artigo. Mas o que parece sobretudo irritar a legislação moderna é a "resistência" aos poderes públicos. Quando se trata disto, os textos facilmente perdem sua calma aparente. A espuma vem à boca de seus defensores, um problema insignificante se torna um tumulto, o passante torna-se um delinqüente. $O$ furor com que seu delito punido mostra a insegurança da nossa ordem pública, o outro lado de sua força. Os monopólios do petróleo ou dos diamantes não se comportam com tanta força e tanta fraqueza, vulnerabilidade e brutalidade; não há quase ninguém que ataque um outsider com tanta conviç̧ão.

A partir do momento em que a criminalidade se organiza ela tende a se tornar um Estado dentro de um Estado. A estrutura dessas sociedades de criminosos reproduz fielmente os governos de quem são rivais e concorrentes. Os bandos de ladrões do final da Idade Média imitavam a organização feudal e uma espécie de vassalagem conservou-se até os nossos dias nas gangs. Naturalmente e com freqüência também se copiaram as formas de organização militar

\section{PARÓdia}

A partir do momento em que a criminalidade se organiza, ela tende a se tornar um Estado dentro de um Estado. A estrutura dessas sociedades de criminosos reproduz fielmente os governos de quem são rivais e concorrentes. Os bandos de ladrões do final da Idade Média imitavam a organização feudal e uma espécie de vassalagem conservou-se até os nossos dias nas gangs. Naturalmente e com freqüência também se copiaram as formas da organização militar. Entre os carbonários do século XIX, houve bandidos fiéis ao rei. Outras "sociedades secretas", como a Camorra, eram mais organizadas em cima do modelo republicano; no entanto, o próprio Salvatore Giuliano se considerava o libertador da Sicília, "pela graça de Deus". A Máfia siciliana imitou a estrutura de um governo patriarcal até os menores detalhes e a estendeu por grandes porções do país; ela dispunha de uma administração muito ramificada, cobrava antecipadamente direitos alfandegários e impostos e tinha seu próprio aparelho judiciário.

Uma simetria análoga se encontra entre a polícia secreta da Rússia tzarista, a Okhrana, e os grupos de conspiradores criados para combatê-la. Organizações rivais muitas vezes tendem a se parecer. É muito difícil

distinguir a partir de suas fisionomias os guarda-costas dos gângsteres dos protetores dos homens do Estado.

Organizações especificamente capitalistas tamberm encontraram suas contrapartes criminosas. Os bandos de gângsteres norte-americanos se intitularam "Sindicato do crime" ou "Murder, Inc."; são calcados nos modelos das grandes corporações, dispõem de seus próprios conselhos fiscais, contabilidades informatizadas, departamentos juríicos e concedem a seu pessoal as mesmas vantagens sociais que uma empresa dá a seus "empregados". Brecht descreveu o fascismo como um racket, da central intermediária de receptação de Peachum para o truste Karfiol. É assim que as sociedades criminosas aparecem como paródias das constituições sociais e políticas comuns e vice-versa. Contudo, na maior parte do tempo, os criminosos seguem apenas manquitolando pelo nível do desenvolvimento geral, o que lhes confere uma aura romanesca. $\mathrm{O}$ fascismo superou muito depressa o tipo expresso por Brecht. Ele naturalmente correspondia ao tipo tradicional do "racha-crânios" (Röhm, por exemplo - a rigor, Göring), mas nos pa- 
rece fora de moda ao lado de figuras como Heydrich, Bormann ou Höss, que anunciam uma estrutura bem mais abstrata da "ordem social".

Assim, a criminalidade permaneceu muito atrasada em relação ao fascismo. Hoje, quando o fascismo em si já não pertence mais ao nosso tempo - o armamento nuclear deixa no limbo o que eram as possibilidades de um Eichmann - o grupo dos criminosos mais avançados provoca o efeito de nos lembrar o passado e é uma injustiça que certos especialistas da estratégia do átomo, autores como Brodie, Morgenstern, Kahn e seus homólogos soviéticos, falem de "uma situação entre dois gângsteres" em seu joguinho de planejamento, enquanto seus cálculos ultrapassam de longe o poder de imaginação de um criminoso: no final das contas, a ambição de dois gângsteres rivais se limita à destruição um do outro, enquanto os cientistas em questão acima de tudo têm em vista os milhões excluídos de seu jogo de planos.

\section{FRASEOLOGIA}

Em nosso universo o delinqüente torna-se assim um personagem relativamente inofensivo, quase simpático, quase humano. Seus motivos são compreensíveis. Enquanto vítima e cúmplice da moral da divisão do trabalho, tornada ilusória, a sociedade o reveste de ornamento mitológico. $O$ gângster não conseguiu acompanhar a progressão irresistível; o desenvolvimento tecnológico acabou com os métodos artesanais de "liquidação" e instaurou procedimentos industriais. Personagens como Trujillo e os inúmeros "benfeitores" de sua espécie hoje no poder em dúzias de países - por mais realista que seja a sua autoridade - são mais testemunhos do atraso histórico dos países que dirigem do que das perspectivas do futuro de sua profissão. $O$ criminoso do gênero antigo, inclusive o criminoso "pai do povo", é um retardatário.

Daŕ as dificuldades semânticas que surgem desde que se tenta aplicar conceitos jurídicos herdados do passado para os malfeitos do "meio" no século XX. Organizađor, executor, controlador da execução, cúmplice, assistente, fáceis de distinguir no momento de uma incursão, vistọ como papéis, confundem-se e perderam o objetivo.

Na sentença de Jerusalém está escrito: “Quando se trata de um crime tão atroz e tão complexo como esse de que nos ocupamos, um crime no qual participaram muitas pessoas em níveis diferentes e de modos tão diversificados - como promotores, organizadores, órgãos executivos, segundo sua respectiva categoria - praticamente não há razões para recorrer-se às costumeiras noções de instigação e complô. Estes crimes foram cometidos em massa, não apenas no que diz respeito às vítimas, mas também no que diz respeito aos autores - o fato de um destes ter estado distante ou muito próximo daquele que, de fato, matou a vítima, não tem nenhuma implicação no grau de sua responsabilidade. Ao contrário, esta responsabilidade aumenta em geral à medida que nos distanciamos de quem manipulou com suas próprias mãos o instrumento da morte".

Não apenas as questões subsidiárias e as classificações do código penal, mas ainda a concepção de crime em si vêm despedaçar-se diante dos personagens que hoje comparecem diante de nossos tribunais ou fazem parte dos estados-maiores encarregados do planejamento de futuros malfeitos. Ao tratar-se Hitler como criminoso comum, se está minimizando o fenômeno que ele representa, transformando-o magicamente em algo concebível. (O Arturo Ui, de Brecht, do começo ao fim, é um understatement, uma exposição deficiente da realidade: o autor se esforça em vão para tornar seu personagem um gângster de peso.) Da mesma forma, falar de um "crime de guerra", qualquer que seja este, é um eufemismo; ́́ como se a guerra moderna pudesse ser combatida pela dissimulação ou falsificação de um resultado: o do imaginável. O crime, totalizado, arrebenta a concepção que dele se possa ter.

Este não é senão um outro exemplo da impotência de nossa linguagem e das nossas concepções diante da situação atômica. A denúncia de um norte-americano à Alta Corte em Washington contra a continuação dos testes atômicos, há alguns anos, era um testemunho repleto de excelentes intenções, mas absurdo. A Alta Corte se declarou incompetente. As nossas noções são incompetentes. O fato de que o nosso aparato militar já não pode mais ser considerado uma arma foi claramente demonstrado por Günter Anders. Neste sentido, uma decisão política que suprimisse todas as outras decisões políticas não mereceria mais este nome. Quando se trata de um ato que não deixa mais nenhum espaço ao questionamento, não pode mais haver responsabilidade no sentido tradicional da palavra. 


\section{SOLUÇĀo FINAL}

"I can build a device - I think I know how to do it to-day, I doubt that it would take me ten yers to do and I doubt it would cost me 10 billion dollars - and this device which I could bury, say, 2.000 feet underground and, if denotaned, it would destroy everybody in the world - at least all unprotected life. It can be done, I believe. In fact, I know it can be done."

(Herman Kahn - discurso do centenário da fundação do MIT/Massachusetts Institute of Technology, 1961.)(19)

Com a teoria dos conjuntos, as ciências matemáticas criaram uma disciplina que permite aos cientistas o cálculo das modificações do infinitamente pequeno e do infinitamente grande. Não existe uma teoria moral dos conjuntos. Quando se tenta descobrir diferenças no interior do Mal imaginário, não estamos unicamente situados diante de dificuldades semânticas. A falha na linguagem apenas serve para demonstrar a falha das nossas faculdades morais diante das nossas próprias possibilidades.

A casuística judiciária não está, até aqui, à altura da situação mais do que o esteja a prática política. A posteridade, preocupada com os preparativos da que a seguirá, hoje procura julgar os responsáveis pela "solução final" de Hitler e seus asseclas. Não há coerência. Esta incoerência é a nossa única esperança, uma esperançazinha muito pequena! Nenhum malfeito futuro poderá contrabalançar o que já foi feito: os malfeitos não permitem a subtração, mas apenas a adição. (Sem a menor dúvida, há uma impotência moral que acredita que Auschwitz possa ser atenuado. Está disseminada principalmente na Alemanha. Ali existem pessoas que empregam a sério a palavra reparação.) As "soluções finais" são irreparáveis e impossíveis de contrabalançar, mesmo diante de um tribunal. É mais uma razão para que o mundo se contenha em submetê-las a um tribunal e mais uma razão também para que este tribunal não baste.

Entre a "solução final" de ontem e a de amanhã, portanto entre duas ações imagináveis, existem diferenciações:

1) A "solução final" de ontem foi realizada. A solução final de amanhã está apenas em preparo. No entanto, é próprio da inconceptibilidade deste ato que não se possa julgá-lo enquanto não for realizado, pois ele não deixará nenhum juiz, acusado ou testemunho.

2) A "solução final" de ontem não foi evitada. A sociedade procura delegar sua preparação e seu impedimento, e isto, aos únicos e mesmíssimos especialistas. Mais do que as próprias soluções finais em si, o seu impedimento não pode ser delegado. Tanto uma como a outra não dependerão da obra de indivíduos, mas da ação de todos: não poderá ser de outra forma. Sem os impotentes, os potentes são impotentes.

3) A "solução final" de ontem foi obra de uma única nação, a nação alemã. A arma da solução final de amanhã pertence a quatro naçōes. Os governos de muitos países esforçam-se por consegui-la. Existem exemplos contrários.

4) O planejamento e a realização da "solução final" de ontem foram efetuados em público. Em 1943 havia pessoas que o ignoravam. Em 1964 há apenas pessoas que o sabem.

5) Os autores da "solução final" de ontem eram reconhecíveis. Usavam um uniforme, suas vítimas usavam uma estrela. Os autores da solução final de amanhã não se distinguem de suas vítimas.

O psiquiatra israelense que examinou Eichmann disse que ele era um "homem completamente normal: parece-me mais normal do que eu mesmo aos meus olhos depois de havê-lo examinado". Outro especialista o considerou um pai de famf́lia exemplar. Eichmann ocupou-se principalmente de documentos, horários, meios de comunicação e estatísticas - entretanto, viu suas vítimas com seus próprios olhos. Esta visão será poupada aos planejadores da última guerra mundial.

Edward Teller é culpado? Será culpado o jornalista que escreveu um artigo para sustentar as pretensões dos políticos alemães em relação ao armamento nuclear? $\mathrm{O}$ mecânico desconhecido de Oklahoma ou de Magnitogorsk é culpado? Mao Tsé-Tung é culpado? É culpado aquele que acredita na quimera da détente enquanto candidatos como Strauss ou Goldwater podem aspirar ao poder da morte? O empreiteiro que constrói um abrigo de concreto armado destinado ao comando é culpado? Existirão ainda culpados futuros? Há inocentes? ... Ou apenas pais de família, amigos da natureza, pessoas normais?

A vitrine de Jerusalém está vazia. 